\title{
Prion biology and bovine spongiform encephalopathy
}

\author{
Biología del prion y encefalopatía espongiforme bovina
}

\author{
OA Peralta* \\ Instituto de Ciencia Animal, Facultad de Ciencias Veterinarias, Universidad Austral de Chile, Valdivia, Chile. \\ Department of Large Animal Clinical Sciences, Virginia-Maryland Regional College of Veterinary Medicine, \\ Blacksburg, Virginia, USA.
}

\begin{abstract}
RESUMEN
La compleja naturaleza de los priones ha intrigado a la comunidad científica durante los últimos 70 años. Desde el primer hallazgo de la infectividad del scrapie y la primera transmisión experimental de este agente en 1937, los priones y las encefalopatías espongiformes transmisibles (EETs) han estado bajo intensa investigación. Las EETs son enfermedades neurodegenerativas y fatales que no poseen diagnóstico temprano, tratamiento o cura. A pesar de sus diversas presentaciones, estas enfermedades provienen de la conversión infecciosa, espontánea o hereditaria de la proteína del prion celular $\mathrm{PrP}^{\mathrm{C}}$ en una isoforma patogénica conocida como $\operatorname{PrP}^{\mathrm{Sc}}$. Según la hipótesis del prion, la $\operatorname{PrP}^{\mathrm{C}}$ tiene la capacidad autocatalítica o inducida de cambiar su configuración secundaria desde una estructura $\alpha$-helicoidal a una configuración predominantemente $\beta$-planar, característica de la PrP ${ }^{\mathrm{Sc}}$. La potencial función fisiológica de la $\mathrm{PrP}^{\mathrm{C}}$ aún no ha sido determinada, sin embargo ha sido vinculada a varios roles biológicos que incluyen adhesión, protección y diferenciación celular. La naturaleza compleja de las EETs ha abierto nuevas interrogantes y presenta nuevos desafios en el área de la biología del prion. La potencial transmisión zoonótica de la Encefalopatía Espongiforme Bovina (EEB) ha despertado preocupación en la comunidad internacional en relación a la bioseguridad de los productos de origen animal. Como consecuencia de este fenómeno, se han realizado numerosas investigaciones para establecer la patogénesis de las EETs y desarrollar métodos de diagnóstico y tratamiento. Sin embargo, se requiere de mayores esfuerzos para dilucidar la compleja naturaleza de este agente y establecer métodos de control para estas enfermedades.
\end{abstract}

Key words: Pathogenic prion protein $\left(\mathrm{PrP}^{\mathrm{Sc}}\right)$, Bovine spongiform encephalopathy (BSE).

Palabras clave: Proteína patogénica del prion $\left(\mathrm{PrP}^{\mathrm{Sc}}\right)$, Encefalopatía espongiforme bovina (EEB).

\section{INTRODUCTION}

The scientific community has been intrigued with the complex nature of prions for over 70 years. The first indication of prion infectivity was reported in 1937 in Scotland after immunization of sheep against louping ill. The vaccines used were accidentally elaborated from brain extracts obtained from sheep infected with scrapie (Gordon 1946). The fact that eight percent of the immunized animals developed scrapie, with the experimental transmission of the agent performed the same year, demonstrated the infectious capacity of scrapie among sheep and goats (Cullie and Chele 1938). In 1959, Hadlow suggested that Kuru, a neurodegenerative disease that affected New Guinea tribes might be similar to scrapie due to similarities in epidemiology, clinical signs and pathological findings. This hypothesis was later confirmed in 1965 by the successful transmission of Kuru to chimpanzees after incubation of 18 to 21 months (Gajdusek et al 1966). One year later, Alper and colleagues reported that the molecular weight

Accepted: 09.03.2011.

* oscarperalta@uach.cl of the scrapie agent was significantly lower compared to a conventional virus (Alper et al 1966). Moreover, Apler showed that the scrapie agent was able to resist doses of ultraviolet radiation (UV) that are sufficient to inactivate nucleic acids. These experiments led to the formulation of the protein-only hypothesis, which described the scrapie agent as a particle conformed by a proteinaceous structure devoid of nucleic acids with the unique capacity to autoreplicate (Griffith 1967). In the 1980s, Prusiner reported abundant experimental data in support of this hypothesis and proposed for the first time the term "prion" to describe the scrapie agent. A prion was defined as small proteinaceous infectious particle which was resistant to inactivation by most procedures that modify nucleic acids (Prusiner 1982). This controversial suggestion supported the idea of a scrapie agent consisting only of an infectious protein and discredited the model that included a small nucleic acid in the core of the protein. Furthermore, one of the most intriguing aspects of the prion biology was the discovery of a host-encoded cellular prion protein or $\operatorname{PrP}^{\mathrm{C}}$ (Oesch et al 1985). This discovery guided to the formulation of the prion hypothesis that postulates that the agent responsible for prion propagation is originated by autocatalytic conversion of $\operatorname{PrP}^{\mathrm{C}}$ into the pathogenic isoform $\mathrm{PrP}^{\mathrm{Sc}}$. 
The unpredictable properties of $\operatorname{PrP}^{\mathrm{Sc}}$ and the potential zoonotic transmission of the bovine spongiform encephalopathy (BSE) have generated intense concern in the international community over animal product biosecurity. Worldwide, 214 people have fallen victim to the variant CJD (vCJD) until January 2011, and epidemiologists predict the presentation of more cases in the coming years due to existing pre-clinical or subclinical infection (Collee et al 2006, NCJDSU ${ }^{1}$ ). In USA, the first case of BSE was detected in 2003 resulting in the ban of meat importation to 53 countries with a drastic drop in $83 \%$ of the imports. Translated into economic terms, BSE produced a loss of 5 billion dollars which corresponded to $4 \%$ of the gross domestic agriculture product (Coffey et al 2005). The complex presentation of Transmissible Spongiform Encephalopathies (TSEs) and the novel properties of the $\mathrm{PrP}^{\mathrm{Sc}}$ have opened many questions yet to be answered. The objective of this report is to present an update of the current knowledge on prion biology and to review some of the features of BSE pathophysiology. During the last years, research in prion biology has mainly focused on determination of the pathogenesis of TSEs and the development of diagnostic and therapeutic methods. However, further research in prion biology will continue to be the foundation for understanding the complex nature of TSEs and how these diseases can be controlled.

\section{PRION BIOLOGY}

\section{$\operatorname{PrP}^{\mathrm{C}}$ STRUCTURE}

The structure of $\operatorname{PrP}^{\mathrm{C}}$ is highly conserved among species and throughout evolution, suggesting an important biological role (Gossert et al 2005). Before post-translational modification, $\mathrm{PrP}^{\mathrm{C}}$ is composed of a sequence of 253 amino acids with a slight variation between species depending on the number of octapeptide repeats (Prusiner and Scott 1997). The octapeptide repeat region is an eightamino acid repetitive motif composed of residues $\mathrm{P}(\mathrm{H} / \mathrm{Q})$ GGG(-/G)WGQ and located in the N-terminal region of the protein (Moore et al 2006). During protein maturation, $\mathrm{PrP}^{\mathrm{C}}$ is exposed to several modifications in the rough endoplasmic reticulum (ER) including replacement of the peptide signal located between amino acids 232-253 with a glycophosphatidylinositol (GPI) anchor. Additionally, two asparagines at amino acids 181-197 are glycosylated and one disulfide bridge is added between two cysteine residues 179-214 (Prusiner 1998, Harris 2003). The mature protein is divided in two distinct regions: a flexible and essentially unstructured $\mathrm{N}$-terminal region between amino acids 23-125 and a C-terminal region containing three alpha-helicoidal structures and a short beta-sheet motif

NCJDSU, National Creuztfeldt-Jackob Disease Surveillance Unit. 2009. The University of Edinburgh. http://www.cjd.ed.ac.uk/ between amino acids 126-231 (Abid and Soto 2006). Asparagine glycosylation will determine variations in the biochemistry of the mature protein resulting in di-, mono-, or un-glycosylated forms with molecular weights of $\sim 34,28$, and $25 \mathrm{~Kb}$, respectively (Russelakis-Carneiro et al 2002). $\mathrm{PrP}^{\mathrm{C}}$ is found as a mixture of these forms with variable proportions depending on the tissue and animal species (Russelakis-Carneiro et al 2002). The expression of $\mathrm{PrP}^{\mathrm{C}}$ is high in the central nervous system; however, recent reports have showed a wide expression in various somatic tissues including thymus, intestine, heart, kidney and skin (Peralta and Eyestone 2009).

The usual cellular location of $\mathrm{PrP}^{\mathrm{C}}$ is attached by the GPI anchor to membrane domains rich in cholesterol and sphingolipids known as lipid raft (Martins et al 2002, DeMarco and Daggett 2005). However, part of the pool of $\mathrm{PrP}^{\mathrm{C}}$ can be internalized via clathrin-mediated endocytosis and accumulate inside the Golgi apparatus. Furthermore, some of the internalized protein is recycled to the cytoplasmatic membrane by kinesin anterograde transport (Hachiya et al 2004). Although the specific location for $\mathrm{PrP}^{\mathrm{Sc}}$ conversion has not yet been determined, it is believed that formation of $\mathrm{PrPSc}^{\mathrm{Sc}}$ occurs at the exterior face of the plasma membrane (Jeffrey et al 2011). Endocytosis of $\mathrm{PrP}^{\mathrm{Sc}}$ may occur mediated by ubiquitin and clathrin molecules into lysosomes for degradation (Jeffrey et al 2011).

\section{PRION GENE STRUCTURE}

The prion gene (PRNP) has homologues in all vertebrates with conserved regions between mammals and birds (Premzl and Gamulin 2007). PRNP is located in chromosome 2 in mouse, 13 in bovine and 20 in human (Sparkes et al 1986, Ryan and Womack 1993). The 5' flanking region of bovine PRNP shows an $89 \%$ homology with the sheep and only 46-62\% homology with the mouse, rat, hamster and human sequences (Inoue et al 1997). Bovine, sheep, mouse and rat $P R N P$ possess three exons with the protein coding sequence located entirely within the third exon (figure 1) (Oesch et al 1985, Inoue et al 1997). Using chloramphenicol acetyltransferase (CAT) plasmids, the promoter region of the bovine gene was detected in the region between -88 and -30 relative to the transcription start site, similar to the rat promoter region (Inoue et al 1997). Several regulatory regions including the promoter has been identified in the bovine $P R N P$ with the major region of transcriptional control located upstream of the initiation site. The promoter sequence is rich in $\mathrm{G}+\mathrm{C}$ features, lacks a TATA box and contains potential binding sites for Sp-1 transcriptional factors (Inoue et al 1997). Several variables have been reported to influence PRNP expression under in vitro conditions including nerve growth factor (NGF), rate of prion infection and epigenetic changes (Bueler et al 1993, Martins et al 2002). 


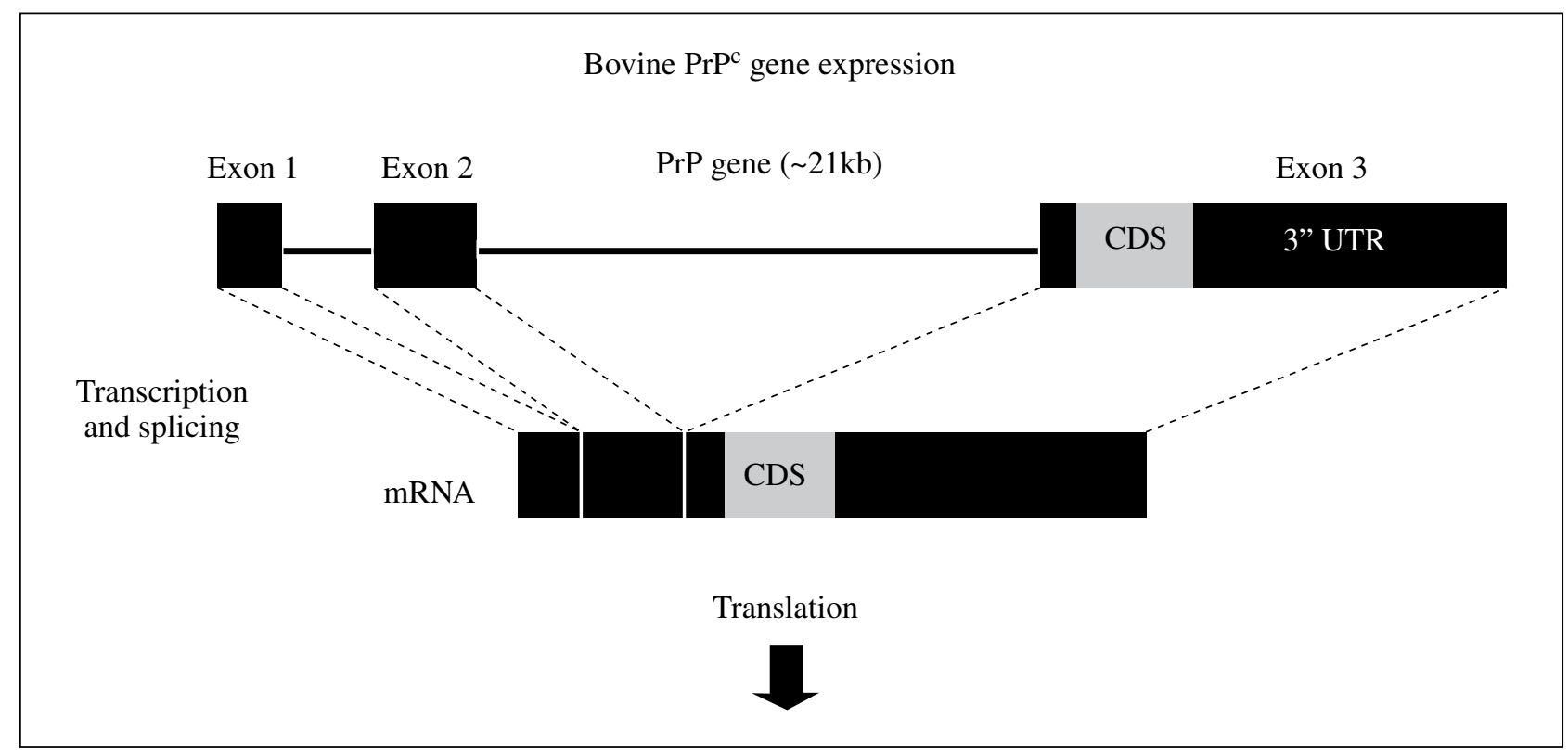

Figure 1. Structure of the $P R N P$ gene and mRNA. The $P R N P$ gene size is approximate $21 \mathrm{~kb}$. After transcription and splicing, the mRNA molecule is formed by exons 1, 2 and 3. Exon 3 carries the coding sequence that encodes the $\operatorname{PrP}^{\mathrm{C}}$ protein after translation.

Estructura del gen $P R N P$ y su mRNA. El gen $P R N P$ posee un tamaño aproximado de 21 kb. Después de la transcripción y empalme la molécula de mRNA queda conformada por los exones 1,2 y 3 . El exon 3 posee la secuencia que codifica al $\operatorname{PrP}^{\mathrm{C}}$ durante la traducción de la proteína.

\section{PrP $^{\mathrm{C}}$ FUNCTION}

Despite intense investigation during recent years, the function of $\mathrm{PrP}^{\mathrm{C}}$ remains enigmatic. Some studies have suggested a cellular protective role of $\operatorname{PrP}^{\mathrm{C}}$ against oxidative stress. Experiments have showed that neurons from PRNP knockout mice and cultured in vitro displayed higher susceptibility to oxidative agents such as hydrogen peroxide, xanthine oxidase and copper ions compared to wild-type neurons (Brown et al 2002). Moreover, brain tissue collected from PRNP knockout mice exhibited biochemical changes including increased levels of protein carbonyls and lipid peroxidation products, which are indicative of oxidative damage (Wong et al 2001). An extensive body of evidence has suggested the binding of $\mathrm{Cu}^{+2}$ ions to the $\mathrm{PrP}^{\mathrm{C}}$ octapeptide repeat region. Copper $\left(\mathrm{Cu}^{+2}\right)$ is an essential element that participates as an enzymatic cofactor in the biochemical pathways of all aerobic organisms. However, $\mathrm{Cu}^{+2}$ can also catalyze the formation of reactive oxygen species such as the hydroxyl radical (Martins et al 2001). The binding of $\mathrm{Cu}^{+2}$ to $\mathrm{PrP}^{\mathrm{C}}$ may limit the capacity to catalyze the formation of such toxic oxidative radicals (Martin et al 2001, Vassallo and Herms 2003). Alternatively, $\operatorname{PrP}^{C}$ may modulate the activity of the $\mathrm{Cu} / \mathrm{Zn}$ superoxide dismutase $(\mathrm{Cu} / \mathrm{Zn} \mathrm{SOD})$ enzyme that showed cellular protective function against oxidative stress (Wechslberger et al 2002, Brown et al 2002).

Several lines of evidence have proposed a cytoprotective role of $\mathrm{PrP}^{\mathrm{C}}$ against internal or environmental stresses that initiate apoptosis. This anti-apoptotic potential is primarily based on the capacity of $\operatorname{PrP}^{\mathrm{C}}$ to inhibit the action of the pro-apoptotic protein Bax (Bounhar et al 2001). Alternatively, $\operatorname{PrP}^{\mathrm{C}}$ may act upstream of Bax, affecting the activity of $\mathrm{BH} 3, \mathrm{Bcl}-2$ or $\mathrm{Bcl}-\mathrm{X}_{\mathrm{L}}$, or downstream, suppressing the effects of Bax in the release of cytochrome $\mathrm{c}$ or activation of Apaf-1 and caspases (Roucou et al 2005, Westergard et al 2007). Other studies have reported a close similarity between the homologous domain of the antiapoptotic protein $\mathrm{Bcl}-2$ and the $\mathrm{PrP}^{\mathrm{C}}$ octapeptide region. This analogy in the protein structure may allow $\operatorname{PrP}^{\mathrm{C}}$ to mimic Bcl-2 function and induce cell survival (Roucou et al 2005, Westergard et al 2007).

In addition to the cytoprotective role, $\operatorname{PrP}^{\mathrm{C}}$ has been also implicated as a cell proliferation and differentiation factor. Recently it was reported that $\mathrm{PrP}^{\mathrm{C}}$-null mice exhibited an impaired capacity of self-renewal of hematopoietic stem cell populations after serial transplantation in the bone marrow (Zhang et al 2006). The potential mitogenic capacity has also been supported by studies showing a decrease in T lymphocyte proliferation in mice devoid of $\operatorname{PrP}^{C}$ (Bainbridge and Walker 2005). The role of $\operatorname{PrP}^{C}$ in differentiation was suggested by high levels of expression in cells that ceased proliferation and became differentiated into neurons during early stages of mice embryogenesis (Tremblay et al 2007). Recently, it has been reported that $\mathrm{PrP}^{\mathrm{C}}$ displayed a positive effect in the proliferation of neural precursor cells and showed a positive correlation with neuronal differentiation (Steele et al 2006, Peralta et al 2011). 
The capacity of $\operatorname{PrP}^{\mathrm{C}}$ to bind to several different molecules has opened the idea that this protein may exert its function in association with a ligand. The location of $\mathrm{PrP}^{\mathrm{C}}$ in the extracytoplasmic face of the lipid bilayer restricts the interaction to transmembrane and secreted proteins. Transmembrane variants of $\mathrm{PrP}^{\mathrm{C}}$ could potentially interact with cytoplasmic partners; however, these forms are normally present in low amounts in the absence of predisposing mutations in the $\mathrm{PrP}^{\mathrm{C}}$ molecule (Stewart and Harris 2001). The membrane association and the interaction with ligands suggest the hypothesis that $\mathrm{PrP}^{\mathrm{C}}$ may activate transmembrane signaling processes associated to neuronal survival, differentiation and neurite outgrowth. The interaction between $\mathrm{PrP}^{\mathrm{C}}$ and the stress inducible protein (STI-1) showed high affinity and specificity resulting in neuroprotective functions through the mediators of the cAMP dependent protein kinase (AMPc/PKA) pathway (Zanata et al 2002). Additionally, interaction with STI-1 induced neuritogenesis through the MAPK pathway as a parallel effect to neuroprotection (Lopes et al 2005). Neuronal growth has also been observed during $\operatorname{PrPC}^{\mathrm{C}}$ interaction with the neuron cell adhesion protein N-CAM after its recruitment from lipid rafts and the activation of Fyn kinase (Santuccione et al 2005). Treatment of cultured neurons with recombinant $\operatorname{PrP}^{\mathrm{C}}$ enhances neurite outgrowth and neuronal survival, concomitant with activation of several kinases, including fyn, PKC, PKA, PI-3 kinase/Akt and ERK (Kanaani et al 2005, Santuccione et al 2005). In addition, studies have showed that $\operatorname{PrP}^{C}$ binds the receptor of laminin in neural cells resulting in dendritic extension, neuronal migration, axonomic regeneration and suppression of cell death induced by kainic acid injection (Martins et al 2001).

\section{PRION HYPOTHESIS}

The prion hypothesis or protein-only hypothesis postulates that the agent responsible for prion propagation is originated by autocatalytic conversion of $\operatorname{PrP}^{\mathrm{C}}$ into the pathogenic isoform (Griffith 1967). Conversion into $\mathrm{PrP}^{\mathrm{Sc}}$ involves a drastic alteration in the protein configuration as well as in its biochemical properties. Crystallography studies indicate that in normal state $47 \%$ of the $\operatorname{PrPC}^{\mathrm{C}}$ structure is composed of $\alpha$-helix and only $3 \% \beta$-sheet secondary configuration. In the conversion process, the $\beta$-sheet configuration is increased to $43-45 \%$ and the $\alpha$-helix structure is reduced to $17-30 \%$ (Pan et al 1993, DeMarco and Dagget 2005) (figure 2). Therefore, the newly formed $\mathrm{PrP}^{\mathrm{Sc}}$ structure is highly planar and stable showing strong resistance to temperature, $\mathrm{pH}$, disinfectants and enzymatic degradation (Taylor 2000).

Additional supporting evidence of the prion hypothesis has been originated from studies that reported resistance to prion infection in mice lacking the PRNP gene (Bueler et al 1993). These knockout models not only evidenced the requirement of a host-encoded $\mathrm{PrP}^{\mathrm{C}}$ protein for the infection process but also allowed a better understanding of the pathogenesis of TSEs. However, the most compelling evidence to probe this theory is yet to be reported. Some researchers claimed that a confirmatory experiment will consist in the in vitro conversion of $\mathrm{PrP}^{\mathrm{C}}$ molecules into a pathogenic isoform with the capacity to induce TSE infection (Chesebro 1998). Mutations induced to recombinant $\operatorname{PrP}^{\mathrm{C}}$ have resulted in destabilization of the protein configuration and formation of a $\mathrm{PrP}^{\mathrm{Sc}}$-like molecule; however, this mutated agent was unable to induce prion disease (Chiesa et al 1998, Bocharova et al 2005). It is possible that additional factors including a transitional form of PrP and host-derived proteins or non-protein compounds (chaperones, glycosaminoglycans or short nucleic acids) are required to sustain in vitro generation of $\mathrm{PrP}^{\mathrm{Sc}}$ (Castilla et al 2005, Aguzzi et al 2007). Hamster PrPC was only converted to $\mathrm{PrP}^{\mathrm{Sc}}$ when cell lysate was added to the reaction (Deleault et al 2005). Moreover, mice co-expressing both human and mice PrP were resistant to prion replication as consequence of the interaction of mice $\mathrm{PrP}^{\mathrm{C}}$ with an additional factor (termed protein $\mathrm{X}$ ) that inhibited human $\mathrm{PrPC}^{\mathrm{C}}$ conversion (Telling et al 1995). Recent studies reported the in vitro generation of $\mathrm{PrP}^{\mathrm{Sc}}$ molecules using a protein misfolding cyclic amplification technique (PMCA) that allows the repetitive amplification of the misfolding event (Castilla et al 2005). Although, the newly formed $\mathrm{PrP}^{\mathrm{Sc}}$ generated by this technique was able to infect wild-type Syrian hamsters, the use of crude brain homogenates to

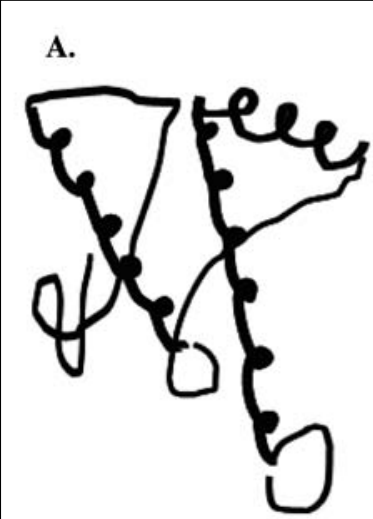

$\operatorname{PrP}^{\mathrm{c}}$

$47 \% \alpha$-helix

$3 \% \beta$-sheet

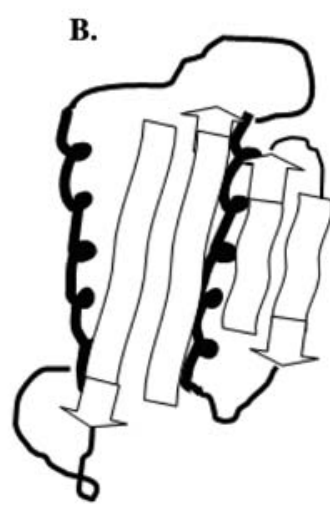

PrPSc

$17-30 \% \alpha$-helix $43-45 \% \beta$-sheet
Figure 2. Structure of $\operatorname{PrP}^{\mathrm{C}}$ and $\mathrm{PrP}^{\mathrm{Sc}}$ isoforms. Both isoforms have important differences in secondary protein configuration. $\mathrm{PrP}^{\mathrm{C}}$ is structured by a high $\alpha$-helicoidal $(47 \%)$ and low $\beta$-sheet configuration (3\%). In contrast, $\mathrm{PrP}^{\mathrm{Sc}}$ is characterized by high $\beta$-sheet (43-45\%) and low $\alpha$-helicoidal (17-30\%) proportion.

Estructura de las isoformas $\operatorname{PrP}^{\mathrm{C}}$ y $\mathrm{PrP}^{\mathrm{Sc}}$. Ambas isoformas poseen importantes diferencias en su configuración secundaria. $\mathrm{La} \mathrm{PrP}^{\mathrm{C}}$ está constituida por un alto porcentaje de estructura $\alpha$-helicoidal (47\%) y bajo porcentaje $\beta$-planar (3\%). En contraste, el $\mathrm{PrP}^{\mathrm{Sc}}$ es caracterizado con una alta proporción de estructura $\beta$-planar (43-45\%) y un bajo contenido $\alpha$-helicoidal (17-30\%). 
amplificate these molecules may have also resulted in the addition of different components responsible for the infection. Further simplification of PMCA has been reported by substituting shaking for sonication as described for the quaking-induced conversion (QuIC) reactions (Atarashi $e t$ al 2008). The QuIC assay can detect within one day less than one lethal intracerebral dose (sub-femtogram amount) of $\mathrm{PrP}^{\mathrm{Sc}}$ in hamster brain homogenates.

Two distinct models have been proposed to explain the autocatalytic conversion of $\mathrm{PrP}^{\mathrm{C}}$, a process not mediated by nucleic acids that challenge the central dogma of molecular biology. The template-assisted model postulates a thermodynamically stable conversion between both PrP isoforms (figure 3). $\mathrm{PrP}^{\mathrm{C}}$ conversion is induced by $\mathrm{PrP}^{\mathrm{Sc}}$ and is mediated by an intermediate and heterodimeric unit before the formation of a homodimeric $\mathrm{PrP}^{\mathrm{Sc}}$. The process is catalyzed by a yet unidentified protein $\mathrm{X}$ that has chaperone-like properties and facilitates aggregation of both isoforms (Cohen and Prusiner 1998). Protein X promotes $\mathrm{PrP}^{\mathrm{C}}$ conversion by binding a discontinuous epitope in the globular $\mathrm{C}$ terminal region of the protein (Kaneko et al 1997). Newly formed $\mathrm{PrP}^{\mathrm{Sc}}$ can eventually agglutinate and precipitate, forming amyloid precursors detected in some TSEs (Prusiner 1990, Cohen 1999). A second model termed nucleation-polymerization proposes a similar thermodynamic equilibrium between both isoforms (figure 3). However, after $\mathrm{PrP}^{\mathrm{C}}$ conversion, the model describes a highly unstable and transient $\mathrm{PrP}^{\mathrm{Sc}}$ molecule that would be stabilized only by forming ordered aggregates. The stabilized oligomers act as nuclei to recruit monomeric $\mathrm{PrP}^{\mathrm{Sc}}$ in a process that displaces the thermodynamic equilibrium and accelerates $\mathrm{PrP}^{\mathrm{Sc}}$ formation (Caughey 2001, Caughey and Lansburry 2003).

Despite a bulk of evidence in support of the prion hypothesis, alternative models suggesting the participation of viral particles, virinos and small RNAs have also been proposed. Co-sedimentation of retroviral RNA with $\mathrm{PrP}^{\mathrm{Sc}}$, and purification of short RNA fragments from infectious fractions suggest the participation of nucleic acids as part of the infectious particle (Akowitz et al 1994). The virino model describes the TSE agent as a proteinaceous structure containing nucleic acids with a virus-like conformation (Chesebro 1998). The finding that prions have a variety of strains that correlates with a species-specific symptomology and histopathology in TSEs has also been used as evidence to support the virino model (Chesebro 1998). However, the strain phenomenon can be explained by the variation in $\mathrm{PrP}^{\mathrm{Sc}}$ protein secondary structure and

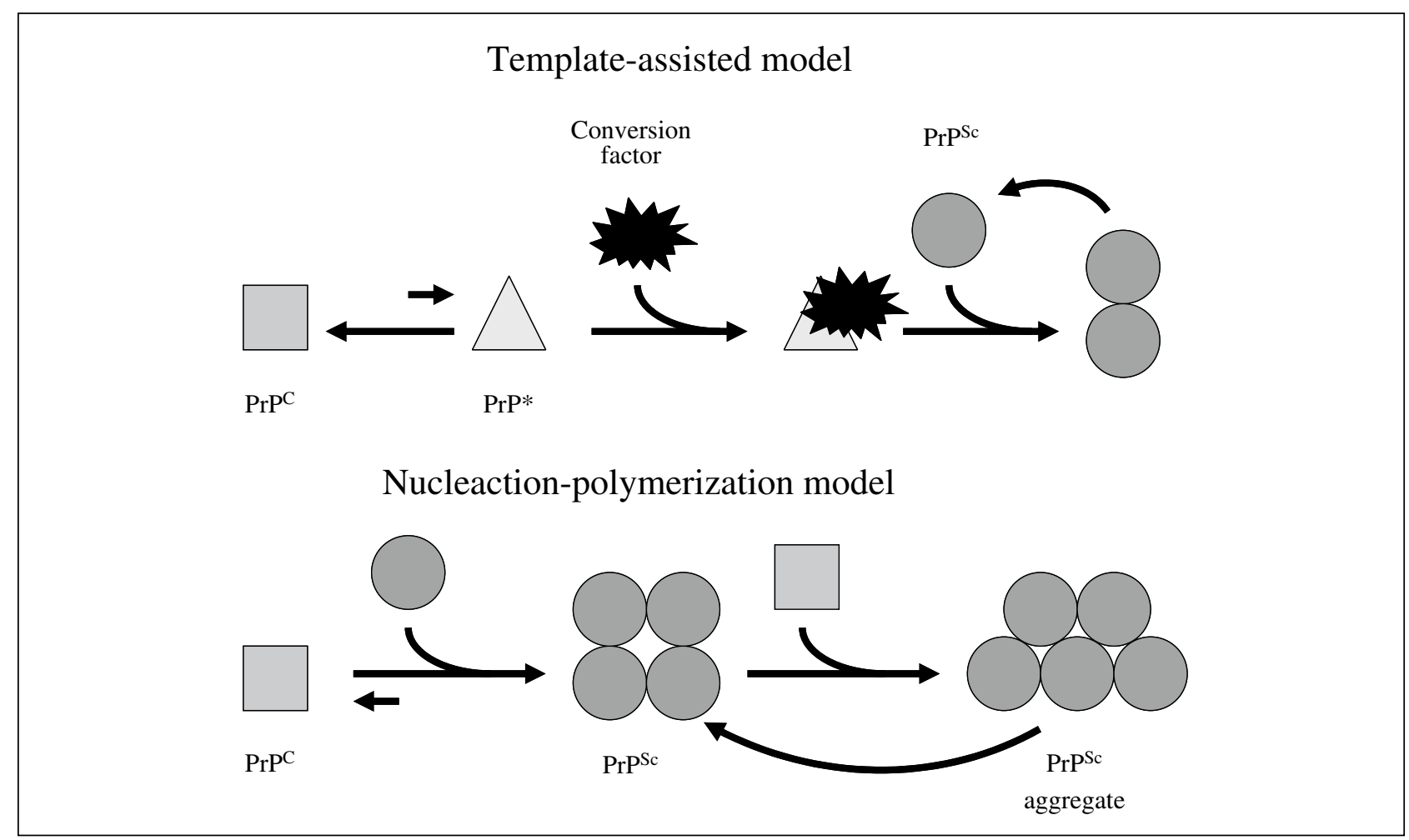

Figure 3. Models for conversion between $\mathrm{PrP}^{\mathrm{C}}$ and $\mathrm{PrP}^{\mathrm{Sc}}$. The template assisted model includes the participation of a conversion factor that mediates $\mathrm{PrP}$ transformation. The nucleation-polymerization model describes a $\mathrm{PrP}^{\mathrm{Sc}}$ heterodimer intermediate complex that induces aggregation and conversion of the molecule. Both models propose a thermodynamic equilibrium for $\operatorname{PrP}^{\mathrm{C}}-\mathrm{PrP}^{\mathrm{Sc}}$ conversion (Soto 2006).

Modelos de conversión entre $\operatorname{PrP}^{\mathrm{C}}$ y $\operatorname{PrP}^{\mathrm{Sc}}$. El modelo de patrón asistido incluye la participación de un factor de conversión que media la transformación del PrP. El modelo de nucleación-polimeración describe un heterodimero intermediario del $\mathrm{PrP}^{\mathrm{Sc}}$ que induce agregación y conversión de la molécula. Ambos modelos proponen un equilibrio termodinámico para la conversión $\operatorname{PrP}^{\mathrm{C}}$-PrP $\mathrm{P}^{\mathrm{Sc}}$ (Soto 2006). 
not necessarily by the existence of viral strains containing nucleic acids (Prusiner 1998).

\section{PrPC ROLE IN TSE PATHOGENESIS}

The pathogenesis of TSEs including the mechanism of neuronal degeneration has not been completely elucidated. It is now becoming clear, however, that $\mathrm{PrP}^{\mathrm{Sc}}$ can kill neurons by virtue of its ability to perturb the normal and physiological activities of $\operatorname{PrP}^{\mathrm{C}}$ (Westergard et al 2007). The presence of $\operatorname{PrPSc}^{\mathrm{Sc}}$ alone in neuronal cells may result in toxic effects by several mechanisms including blocking axonal transport, interfering with synaptic function, or triggering apoptotic pathways (Westergard et al 2007). Alternatively, the potential association between $\mathrm{PrP}^{\mathrm{Sc}}$ and $\mathrm{PrP}^{\mathrm{C}}$ during the pathogenic process may result in the loss of $\mathrm{PrP}^{\mathrm{C}}$ anti-apoptotic activity, resulting in neuronal death. Evidence that argues against this theory is based on the small phenotypic effect and lack of any features of TSEs observed after ablation of $\operatorname{PrP}^{C}$ either prenatally or postnatally (Bueler et al 1992, Mallucci et al 2002). However, it is possible that neurodegeneration may be consequence of both loss and gain in function, by loss of the cytoprotective activity of $\mathrm{PrP}^{\mathrm{C}}$ that may become essential in the disease state due to cellular or organism stress.

Another hypothesis for the TSE-pathogenic effect postulates the alteration or subversion of the normal $\mathrm{PrP}^{\mathrm{C}}$ neuroprotective function. $\mathrm{PrP}^{\mathrm{C}}$ may act as a membraneanchored signal transduction that transmits the $\mathrm{PrP}^{\mathrm{Sc}}$ toxic effect (Chesebro et al 2005). Neurons obtained from $\operatorname{PrP}^{\mathrm{C}}$ knockout mice and cultured in vitro were resistant to apoptosis induced by exposure to the synthetic peptide PrP 106-126 (Brown et al 1994). This phenomenon may be the consequence of a $\mathrm{PrP}^{\mathrm{Sc}}$-induced aggregation of cell surface $\operatorname{PrP}^{C}$ that generates a neurotoxic rather than a neuroprotective signal. Cross-linking of $\mathrm{PrP}^{\mathrm{C}}$ using antiPrP antibodies resulted in apoptosis of neurons in vivo (Solforosi et al 2004). Alternatively, amino acid sequences (PrP $\Delta 105-125$ ) in the $\operatorname{PrP}^{\mathrm{C}}$ structure have been reported to have receptor activity with cytoprotective functions. These receptor sequences may be blocked by $\mathrm{PrP}^{\mathrm{Sc}}$ resulting in the delivery of a neurotoxic signal (Li et al 2007).

\section{BOVINE SPONGIFORM ENCEPHALOPATHY}

\section{EPIDEMIOLOGY}

Bovine spongiform encephalopathy (BSE) was reported for the first time in the UK in 1986 (Wells et al 1987). The disease achieved epidemic proportions during the 1990s with more than 182,000 cases worldwide recorded between November of that year and December of 2010. BSE has been detected in 24 countries showing a decreasing trend in the number of cases since 2003 until 2010 (2167 and 37 cases, respectively) (OIE 2011).
The origin of BSE has not been clarified but several theories have been formulated. One of these theories postulates the inter-species transmission from scrapieinfected sheep to cattle. Thus, cows became infected after consumption of protein concentrate made from carcasses of sheep contaminated with scrapie. Scrapie has affected sheep for 200 years, is endemic in the UK and is present in a number of countries worldwide (Schwartz 2003). Although contamination of feed with infected ovine carcasses is possible; experimental transmission of scrapie agent to the bovine has proved difficult, making this hypothesis improbable (Cutlip et al 1994). A second theory involves the spontaneous destabilization and conversion of $\operatorname{PrP}^{\mathrm{C}}$ into $\mathrm{PrP}^{\mathrm{Sc}}$. Spontaneous or atypical BSE cases have been reported recently, and animals affected by this disease may have served as a source of protein supplements for cattle feed thus spreading the disease in this manner (Capiobianco et al 2007). However, one of the most controversial theories to explain the contamination of animal concentrate is the human origin of BSE. Funeral rituals in areas of India involve the cremation of cadavers and the disposal of human remains to rivers. Some of these remains may have been collected by "bonepickers" and used to elaborate bone meal that eventually might have been contaminated with human TSE. By this process, contaminated bone and meat meal exported from the India to Europe and used for animal consumption may have served as a source of BSE transmission (Colchester and Colchester 2005).

\section{CAUSAL AGENT}

Detection of $\mathrm{PrP}^{\mathrm{Sc}}$ is highly correlated with the pathology and diagnosis of BSE. However, the sole presence of $\mathrm{PrP}^{\mathrm{Sc}}$ as the pathogenic agent of animal TSEs has been debated (Jeffrey and Gonzalez 2007). Mice infected with scrapie agent developed lesions in areas of the brain that showed low levels of PrPSc (Parchi and Gambetti 1995). Moreover, no brain damage was reported in transgenic mice over-expressing $\mathrm{PrP}^{\mathrm{Sc}}$ (Chiesa and Harris 2001). These reports suggest that cellular damage is a consequence not exclusively of $\mathrm{PrP}^{\mathrm{Sc}}$ but also require the participation of additional cofactors including a transitional form of PrP and host-derived proteins or non-protein compounds (glycosaminoglycans or short nucleic acids) (Aguzzi et al 2007). In this scenario, $\operatorname{PrP}^{C}$ may play an important role as a mediator in $\mathrm{PrP}^{\mathrm{Sc}}$ pathogenesis. Mice infected with $\mathrm{PrP}^{\mathrm{Sc}}$ in which PRNP gene was knocked out from the beginning or during the infectious process showed that $\mathrm{PrP}^{\mathrm{C}}$ expression is required for cellular damage (Brandner et al 1996, Mallucci et al 2003).

\section{PATHOGENESIS}

There are several origins of prion disease pathogenesis that remain to be understood. It is believed that the BSE agent is passed under natural conditions from one animal to 
the other through oral ingestion. Indeed, the transmission of the $\mathrm{PrP}^{\mathrm{Sc}}$ agent by the oral pathway has great relevance in some TSEs (e.g. variant Creutzfeldt-Jakob disease, Kuru and BSE). This is not the case in spontaneous forms of this disease in which genetic predisposition seems to be the causative factor (e.g. spontaneous Creutzfeldt-Jakob). Although oral ingestion of the agent is the most commonly known form of contamination, other ways of infection cannot be overlooked, such as injection of contaminated products, skin injuries, blood transfusion or iatrogenic ways (Mabbott and MacPherson 2006, Houston et al 2008). The transport of $\mathrm{PrP}^{\mathrm{Sc}}$ through the intestinal mucosa is mediated by microfold cells (M cells) located within the epithelium villus and follicle-associated epithelium (FAE) of the Peyer's patches, through the process of transcytosis (Heppner et al 2001). Under physiological conditions, M cells sample contents of the intestinal lumen and present these antigens to the host immune system for immunomodulation. Some pathogenic microorganisms and potentially $\mathrm{PrP}^{\mathrm{Sc}}$ can exploit $\mathrm{M}$ cells transcytosis to gain entry into mucosal tissues (Neutra et al 1996). The transport of TSE agents across the intestinal epithelium; however, might not be entirely mediated by M-cell-transcytosis. $\mathrm{PrP}^{\mathrm{Sc}}$-proteon complexes originated from CJD brain homogenate can be endocytosed by intestinal epithelial cells (Caco- 2 cells) and transcytosed in vesicular structures by a ferritin-dependent mechanism (Mishra et al 2004).

After transport through the intestinal mucosa, $\mathrm{PrP}^{\mathrm{Sc}}$ particles are captured by several types of cells including macrophages, lymphocytes and dendritic cells (DCs) and presented to follicular dendritic cells (FDCs) in the lamina propia. The precise involvement of macrophages in TSE pathogenesis is uncertain but these cells may mediate the transport and also the impairment of $\mathrm{PrP}^{\mathrm{Sc}}$ accumulation. A recent in vitro study showed that macrophage depletion resulted in an earlier increase in $\mathrm{PrP}^{\mathrm{Sc}}$ accumulation in the lymphoid tissue (Maignien et al 2005). Lymphocytes are also situated intraepithelial, but are unlikely to be involved in transporting $\mathrm{PrP}^{\mathrm{Sc}}$ as they do not acquire measurable levels of this agent following intra-intestinal exposure (Huang et al 2002). DCs are a distinct lineage from stromal derived FDCs that sample antigens in the periphery and deliver them to lymphoid tissues to initiate an immune response (Shortman and Liu 2002). The location of DCs beneath intraepithelial M cells and their capacity to acquire intestinal antigens by inserting their dendrites between tight junctions (independently from $M$ cells) make these cells good candidates to transport $\mathrm{PrP}$ to lymphoid tissues (Beekes and McBride 2000).

Analysis of the distribution of the $\mathrm{PrP}^{\mathrm{Sc}}$ within the nervous system of orally inoculated rodents and livestock indicates that the agent subsequently spreads from the gut-associated lymphoid tissue (GALT) to the CNS through the enteric nervous system in a process known as neuroinvasion (Beekes and McBride 2000, Hoffmann et al 2007, van Keulen et al 2008). The enteric nervous system is an important component of the autonomic nervous system and regulates intestinal motility and secretions through stimuli from sympathetic and parasympathetic nerves. $\mathrm{PrP}^{\mathrm{Sc}}$ reaches the CNS by spreading in a retrograde direction along efferent fibers of both sympathetic and parasympathetic nerves until they contact the spinal cord. It is not understood how $\operatorname{PrP}^{\mathrm{Sc}}$ initially spread from the FDCs to the peripheral nervous system. This process may be mediated by mobile intermediate cells or exosomes derived from FDCs, DCs or macrophages that transport $\mathrm{PrP}^{\mathrm{Sc}}$ particles from FDCs to the peripheral nervous system (Mabbott and MacPherson 2006). The haematogenous route may represent a parallel or alternative pathway of neuroinvasion to ascending infection via the autonomic nervous system. Despite the protective function of the blood-brain barrier, the circumventricular organs are more permissive than other brain areas to the passage of large molecules and may act as portals of entry of infection (Siso et al 2010).

\section{HISTOPATHOLOGICAL CHANGES}

In general, histopathological changes observed in TSEs are associated with spongiform degeneration, vacuolization, astrogliosis and $\mathrm{PrP}^{\mathrm{Sc}}$ deposition (Budka 1995, McDonald et al 1996). However, astrogliosis and neuronal loss are not evident in BSE compared to other TSEs. The presence of amyloid plaques are rare in classic BSE and are mostly found in the thalamus. In contrast, atypical BSE or Bovine Amyloidotic Spongiform Encephalopathy (BASE) has been characterized by the presence of large plaques mainly in the white matter. The molecular signature of BASE also differs from BSE and resembles CJD (Casalone et al 2004). Several theories have been proposed to explain BASE presentation including spontaneous occurrence of TSE in animals as in sporadic CJD. Classic BSE is also characterized by spongiosis and vacuolization of the neuropil and neuronal bodies through simple or multiple vacuoles in the neuronal perikarya (Wells et al 1989). Neural tissues most consistently and severely affected are the solitary tract nucleus, the spinal tract nucleus of the trigeminal nerve, and the central gray matter of the midbrain (Wells et al 1989). Neuropil vacuolization of the target nuclei is considered to be pathognomic in BSE. Intraneuronal vacuolation is also observed in BSE, but this feature alone in the absence of neuropil vacuolation is not confirmatory. Vacuolated neurons particularly in certain locations such as the red nucleus may be an incidental finding in cattle (Gavier-Widen et al 2001). Immunohistochemical analysis consistently reveals $\operatorname{PrP}^{\mathrm{Sc}}$ accumulation in the brain, with distribution similar to but often more widespread than neuropil vacuolization (Wells and Wilesmith 1995). Patterns of $\mathrm{PrP}^{\mathrm{Sc}}$ deposition in the brain include intraneuronal, perineuronal, linear, fine punctuate and coarse particulate (Casalone et al 2006). $\mathrm{PrP}^{\mathrm{Sc}}$ cannot readily be detected in tissues outside bovine CNS; however, limited 
involvement of the Peyer's patches has been documented in experimentally induced and naturally acquired cases of BSE (Terry et al 2003).

\section{DIAGNOSIS}

All cattle BSE diagnostic methods currently available require post-mortem confirmation. Despite characteristic clinical signs, diagnosis of BSE cannot rely solely on the clinical course and requires histopathological analysis. Initial histopathological diagnosis is based on vacuolar changes in the brain, observation of florid plaques, astrogliosis and neuronal loss. However, presentation of cases with no evident or ambiguous histopathological changes requires confirmation through more specific and sensitive methods such as immunohistochemistry, western blot and/ or ELISA (Gavier-Widen et al 2005, OIE 2004). Given the pivotal role played by $\mathrm{PrP}^{\mathrm{Sc}}$ in TSE pathogenesis, diagnostic methods rely on $\mathrm{PrP}^{\mathrm{Sc}}$ detection by specific antibodies and partial proteinase $\mathrm{K}$ digestion that allows differentiation between both PrP isoforms. In recent years, some antibodies have claimed to differentiate between $\mathrm{PrP}^{\mathrm{C}}$ and $\mathrm{PrPS}$; however, none of these molecules have proved suitable for direct identification of $\mathrm{PrP}^{\mathrm{Sc}}$ (Korth $e t$ al 1997, Curin et al 2004).

Consistent early accumulation of $\mathrm{PrP}^{\mathrm{Sc}}$ and vacuolar lesions in the medulla oblongata at the level of the obex (brainstem) make this area of the brain an optimal site for the post-mortem diagnosis of BSE (Schaller et al 1999). An appropriate sample for BSE diagnosis should include the solitary and trigeminal tract nuclei (Jeffrey and Gonzales 2004). The brainstem sample should be promptly refrigerated (at $4{ }^{\circ} \mathrm{C}$ not frozen) or fixed in $10 \%$ formaldehyde until shipment to the diagnostic laboratory to avoid post-mortem decomposition (Gavier-Widen et al 2005, USDA 2005).

Several diagnostic methods based on immunological techniques have been validated and officially accepted for BSE. Currently, the BioRad diagnostic immunoassay is used as a rapid test for BSE detection. Advantages of this method include easy manipulation, fast results $(24 \mathrm{~h})$, high sensitivity, and detection of $\mathrm{PrP}^{\mathrm{Sc}}$ infection during preclinical stages (Soto 2006). However, presence of false positive results recommends the use of confirmatory techniques (USDA 2005). High specificity, visualization of the spongiform lesions and $\mathrm{PrP}^{\mathrm{Sc}}$-specific immunostaining make the immunohistochemistry a primary choice for confirmatory test for BSE diagnosis. Mounted tissue sections are exposed to proteinase $\mathrm{K}$ digestion and epitope unmasking through immersion in citric buffer. $\mathrm{PrP}^{\mathrm{Sc}}$ is detected by incubation with anti-PrP antibodies followed by secondary antibodies associated to horseperoxidase staining or fluorescence dyes (OIE 2004). Samples with moderate levels of decomposition may not be suitable for the immunohistochemistry method but may be used for western blot analysis. This method has similar specificity compared to immunohistochemistry but does not allow histological analysis. Currently, this technique can be performed in a short period of time with high sensitivity. Tissue sample lysates are treated with proteinase $\mathrm{K}$ for $\mathrm{PrP}^{\mathrm{C}}$ digestion. Total protein contained in samples are separated by electrophoresis in $12 \%$ SDS polyacrylamide gels and blotted into nitrocellulose or polyvinylidene fluoride (PVDF) membranes. $\operatorname{PrP}^{\mathrm{Sc}}$ is specifically detected by incubation with anti-PrP antibodies followed by secondary antibodies.

The requirement of a pre-mortem diagnostic method is desirable considering the inability to apply conventional methods for nucleic acids or antiserum detection such as PCR or ELISA. During the last years, substantial efforts have been applied in the development of $\mathrm{PrP}^{\mathrm{Sc}^{\mathrm{S}} \text {-specific }}$ antibodies for the potential diagnostic of infectivity in fluids and tissues. Despite the significant differences in secondary structure between both PrP isoforms, the development of such antibodies is still incomplete (Kascsak et al 1997, Curin et al 2004). $\mathrm{PrP}^{\mathrm{Sc}}$ has been detected in the blood of infected animals, which represents a potential strategy for early diagnosis of TSEs (Castilla et al 2005). However, levels of $\mathrm{PrP}^{\mathrm{Sc}}$ in blood are very low making even highly sensitive techniques such as immunocapillary electrophoresis unable to detect the agent (Schmerr and Jenny 1998). One important step in the development of such a diagnostic tool was the recently reported development of a protein misfolding cyclic amplification technique (PMCA). This method was able to simulate $\mathrm{PrP}^{\mathrm{Sc}}$ replication in a test tube and increase the detection threshold of this protein by 10 million times (Castilla et al 2005, Thorne and Terry 2008). This new technology enables an efficient, specific and rapid detection of prions offering great promise for developing a noninvasive early diagnosis of TSEs.

\section{CONCLUSIONS}

The establishment of the controversial prion hypothesis opened a new perspective in protein biology that involved the participation of these molecules in diseases as pathogenic and infectious agents. Not only TSEs, but other neurodegenerative diseases such as Alzheimer's have shown to be associated with the misfolding and deposition of host-encoded proteins with severe neuropathology. Currently, there are no ways to cure, treat or immunize against these diseases, and the consequences for public health and economic costs have proven to be tremendous. However, important advances during the last years in the evaluation of prion biology have allowed a better understanding of the pathogenesis of these diseases and have opened new opportunities for treatment.

\section{SUMMARY}

The complex nature of prions has intrigued the scientific community during the last 70 years. Since the first indication of scrapie infectivity 
and the experimental transmission of the scrapie agent in 1937, prions and their associated transmissible spongiform encephalopathies (TSEs) have been under constant investigation. TSEs are neurodegenerative and fatal diseases with no early diagnosis, treatment or cure. Despite their diverse presentations, all TSEs stem from the infectious, spontaneous or hereditary conversion of the host-encoded cellular prion protein $\mathrm{PrP}^{\mathrm{C}}$ into the pathogenic isoform $\mathrm{PrP}^{\mathrm{Sc}}$. Based on the prion hypothesis, $\mathrm{PrP}^{\mathrm{C}}$ has the autocatalytic or induced capacity to change its secondary configuration from a mainly $\alpha$-helix structure into predominant $\beta$-sheet configuration. Another enigmatic aspect of the prion biology is the potential physiological function of $\mathrm{PrP}^{\mathrm{C}}$, a protein that is widely distributed in mammalian tissues and intensely expressed in the nervous system. $\mathrm{PrP}^{\mathrm{C}}$ has been associated to several biological roles including cellular adhesion, protection and differentiation. The unpredictable properties of the $\mathrm{PrP}^{\mathrm{Sc}}$ and the complex presentation of TSEs have opened many questions yet to be answered. The potential zoonotic transmission of the bovine spongiform encephalopathy (BSE) has generated intense concern in the international community over animal product biosecurity. During the last years, research in prion biology has mainly focused on determination of the pathogenesis of TSEs and the development of diagnostic and therapeutic methods. However, further research in prion biology is required in order to understand the complex nature of TSEs and how these diseases can be controlled.

\section{REFERENCES}

Abid K, C Soto. 2006. The intriguing prion disorders. Cell Mol Life Sci 63, 2342-2351.

Aguzzi A, M Heikenwalder, M Polymenidou. 2007. Insights into prion strains and neurotoxicity. Nat Rev Mol Cell Biol 8, 552-561.

Akowitz A, T Sklaviadis, L Manuelidis. 1994. Endogenous viral complexes with long RNA cosediment with the agent of Creutzfeldt-Jakob disease. Nucleic Acids Res 22, 1101-1107.

Alper T, DA Haig, MC Clarke. 1966. The exceptionally small size of the scrapie agent. Biochem Res Commun 22, 278-284.

Atarashi R, JM Wilham, L Christensen, AG Hughson, RA Moore, LM Johnson, HA Onwubiko HA, SA Priola, B Caughey. 2008. Simplified ultrasensitive prion detection by recombinant PrP conversion with shaking. Nat Methods 5, 211-212.

Bainbridge J, KB Walker. 2005 The normal cellular form of prion protein modulates T cell responses. Immunol Lett 15, 147-150.

Beekes M, PA McBride. 2000. Early accumulation of pathological PrP in the enteric nervous system and gut-associated lymphoid tissue of hamsters orally infected with scrapie. Neurosci Lett 278, 181-184.

Bocharova OV, L Breyedo, AS Parfenov, VV Salnikov, IV Baskakov. 2005. In vitro conversion of full-length mammalian prion protein produces amyloid form with physical properties of $\operatorname{PrP}(\mathrm{Sc}) . J$ Mol Biol 346, 645-659.

Bounhar Y, Y Zhang, CG Goodyer, A LeBlanc. 2001. Prion protein protects human neurons against Bax-mediated apoptosis. J Biol Chem 19, 39145-39149.

Brandner S, S Isenmann, A Raeber, M Fischer, A Sailer, Y Kobayashi, S Marino, C Weissmann, A Aguzzi. 1996. Normal host prion protein necessary for scrapie-induced neurotoxicity. Nature 379, 339-343.

Brown DR, J Herms, HA Kretzschmar. 1994. Mouse cortical cells lacking cellular PrP survive in culture with a neurotoxic PrP fragment. NeuroReport 5, 2057-2060.

Brown DR, RS Nicholas, L Canevari. 2002. Lack of prion protein expression results in a neuronal phenotype sensitive to stress. J Neurosci Res 67, 211-224.

Budka H, A Aguzzi, P Brown, JM Brucher, O Bugiani, F Gullotta, M Haltia, JJ Hauw, JW Ironside, K Jellinger. 1995. Neuropathological diagnostic criteria for Creutzfeldt-Jakob disease (CJD) and other human spongiform encephalopathies (prion diseases). Brain Pathol $5,459-466$
Bueler H, M Fischer, Y Lang, H Fluethmann, HP Lipp, SJ DeArmond, SB Prusiner, M Aguet, C Wissmann. 1992. Normal development and behavior of mice lacking the neuronal cell-surface PrP protein. Nature 356, 577-582.

Bueler H, A Aguzzi, A Sailer, RA Greiner, P Autenried, M Aguet, C Weissman. 1993. Mice devoid of PrP are resistant to scrapie. Cell 73, 1339-1347.

Capobianco R, C Casalone, S Suardi, M Mangieri, C Miccolo, L Limido, M Catania, G Rossi, G Di Fede, G Giaccone, MG Bruzzone, L Minati, C Corona, P Acutis, D Gelmetti, G Lombardi, MH Groschup, A Buschmann, G Zanusso, S Monaco, M Caramelli, F Tagliavini. 2007. Conversion of the BASE prion strain into the BSE strain: the origin of BSE? PloS Pathog 3, e31.

Casalone C, G Zanusso, P Acutis, S Ferrari, L Capucci, F Tagliavini, S Monaco, M Caramelli. 2004. Identification of a second bovine amyloidotic spongiform encephalopathy: molecular similarities with sporadic Creutzfeldt-Jakob disease. Proc Natl Acad Sci USA 101, 3065-3070

Casalone C, M Caramelli, Crescio MI, YI Spencer, MM Simmons. 2006. BSE immunohistochemical patterns in the brainstem: a comparison between UK and Italian cases. Acta Neuropathol 111, 444-449.

Castilla J, P Saa, C Hetz, C Soto. 2005. In vitro generation of infectious scrapie prions. Cell 121, 195-206.

Caughey B. 2001. Interactions between prion protein isoforms: the kiss of death? Trends Biochem Sci 26, 235-242.

Caughey B, PT Lansbury. 2003. Protofibrils, pores, fibrils, and neurodegeneration: separating the responsible protein aggregates from the innocent bystanders. Annu Rev Neurosci 26, 267-298.

Chesebro B. 1998. BSE and prions: uncertainties about the agent. Science 279, 42-43.

Chesebro B, M Trifilo, R Race, K Meade-White, C Teng, R LaCasse, L Raymond, C Favara, G Baron, S Priola, B Caughey, E Masliah, M Oldstone. 2005. Anchorless prion protein results in infectious amyloid disease without clinical scrapie. Science 308, 1435-1439.

Chiesa R, P Piccardo, B Ghetti, DA Harris. 1998. Neurological illness in transgenic mice expressing a prion protein with an insertional mutation. Neuron 21, 1339-1351.

Chiesa R, DA Harris. 2001. Prion diseases: what is the neurotoxic molecule? Neurobiol Dis 8, 743-763.

Coffey B, J Mintert, S Fox, T Schroeder, L Valentin. 2005. The economic impact of BSE on the US beef industry: product value losses, regulatory costs, and consumer reactions. Tech Rep Agricultural Experiment Station and Cooperative Extension Service No. 2678, Kansas State University, Kansas, USA.

Cohen FE, SB Prusiner. 1998. Pathologic conformations of prion proteins. Апnи Rev Biochem 67, 793-819.

Cohen FE. 1999. Protein misfolding and prion diseases. J Mol Biol 293, 313-320.

Colchester AC, NT Colchester. 2005. The origin of bovine spongiform encephalopathy: the human prion disease hypothesis. Lancet 366 , 856-861.

Collee JG, R Bradley, PP Liberski. 2006. Variant CJD (vCJD) and bovine spongiform encephalopathy (BSE): 10 and 20 years on: part 2. Folia Neuropathol 44, 102-110.

Collinge J. 2001. Prion diseases of humans and animals: their causes and molecular basis. Annu Rev Neurosci 24, 519-550

Cullie J, PL Chele. 1938. La tremblante du mouton est bien inoculable C. R. Acad Sci (Paris) 206, 78-79.

Curin Serbec V, M Bresjanac, M Popovic, K Pretnar Hartman, V Galvani, R Rupreht, M Cernilec, T Vranac, I Hafner, R Jerala. 2004. Monoclonal antibody against a peptide of human prion protein discriminates between Creutzfeldt-Jakob disease-affected and normal brain tissue. J Biol Chem 279, 3694-3698.

Cutlip RC, JM Miller, RE Race, AL Jenny, JB Katz, HD Lehmkuhl, HM DeBey, MM Robinson. 1994. Intracerebral transmission of scrapie to cattle. J Infect Dis $169,814-820$ 
Deleault NR, JC Geoghegan, K Nishina, R Kascsak, RA Williamson, $S$ Supattapone. 2005. Protease-resistant prion protein amplification reconstituted with partially purified substrates and synthetic polyanions. J Biol Chem 280, 26873-26879.

DeMarco ML, V Daggett. 2005. Local environmental effects on the structure of the prion protein. C R Biol 328, 847-862.

Gajdusek DC, CJ Jr Gibbs, M Alpers. 1966. Experimental transmission of a kuru-like syndrome to chimpanzees. Nature 209, 794-96.

Gavier-Widen D, GA Wells, MM Simmons, JW Wilesmith, J Ryan. 2001. Histological observations on the brains of symptomless 7-year-old cattle. J Comp Pathol 124, 52-59.

Gavier-Widen D, Stack MJ, Baron T, Balachandran A, Simmons M. 2005. Diagnosis of transmissible spongiform encephalopathy in animals: a review. J Vet Diagn Invest 17, 509-527.

Gordon WS. 1946. Advances in Veterinary Research. Vet Rec 58, 516.

Gossert AD, S Bonjour, DA Lysek, F Fiorito, K Wuthrich. 2005. Prion protein NMR structures of elk and of mouse/elk hybrids. Proc Natl Acad Sci USA 102, 646-650.

Griffith JS. 1967. Self-replication and scrapie. Nature 215, 1043 1044.

Hachiya NS, K Watanabe, M Yamada, Y Sakasegawa, K Kaneko. 2004. Anterograde and retrograde intracellular trafficking of fluorescent cellular prion protein. Biochem Biophys Res Comm 315, 802-807.

Hadlow WJ. 1959. Scrapie and kuru. Lancet 2, 289-290.

Harris DA. 2003. Trafficking, turnover and membrane topology of PrP. Br Med Bull 66, 71-85.

Heppner FL, AD Christ, MA Klein, M Prinz, M Fried, JP Kraehenbuhl, A Aguzzi. 2001. Transepithelial prion transport by M cells. Nature Med 7, 976-977.

Hoffmann C, U Ziegler, A Buschmann, A Weber, L Kupfer, A Oelschlegel, B Hammerschmidt, MH Groschup. 2007. Prions spread via the autonomic nervous system from the gut to the central nervous system in cattle incubating bovine spongiform encephalopathy. J Gen Virol 88, 1048-1055.

Houston F, S McCutcheon, W Goldmann, A Chong, J Foster, S Siso, L Gonzalez, M Jeffrey, N Hunter. 2008. Prion diseases are efficiently transmitted by blood transfusion in sheep. Blood 1, 4739-4745.

Huang FP, CF Farquhar, NA Mabbot, ME Bruce, GG MacPherson. 2002. Migrating intestinal dendritic cells transport PrPSc from the gut. J Gen Virol 83, 267-271.

Inoue S, M Tanaka, M Horiuchi, N Ishiguro, M Shinagawa. 1997. Characterization of the bovine protein gene: The expression requires interaction between the promoter and intron. $J$ Vet Med Sci 59, 175-183.

Jeffrey M, L Gonzales. 2004. Pathology and pathogenesis of bovine spongiform encephalopathy and scrapie. Curr Topics Microbiol Immunol 284, 65-97.

Jeffrey M, L Gonzales. 2007. Classical sheep transmissible spongiform encephalopathies: pathogenesis, pathological phenotypes and clinical disease. Neuropathol Appl Neurobiol 33, 373-394.

Jeffrey M, G McGovern, S Siso, L Gonzalez. 2011. Cellular and subcellular pathology of animal prion diseases: relationship between morphological changes, accumulation of abnormal prion protein and clinical disease. Acta Neuropathol 121, 113-134.

Kanaani J, SB Prusiner, J Diacovo, S Baekkeskov, G Legname. 2005. Recombinant prion protein induces rapid polarization and development of synapses in embryonic rat hippocampal neurons in vitro. J Neurochem 95, 1373-1386.

Kaneko K, L Zulianello, M Scott, CM Cooper, AC Wallace, TL James, FE Cohen, SB Prusiner. 1997. Evidence for protein X binding to a discontinuous epitope on the cellular prion protein during scrapie prion propagation. Proc Natl Acad Sci USA 94, 10069-10074.

Kascsak RJ, R Fersko, D Pulgiano, R Rubenstein, RI Carp. 1997. Immunodiagnosis of prion disease. Immunol Invest 26, 259-268.

Korth C, B Stierli, P Streit, M Moser, O Schaller, R Fischer, W SchulzSchaeffer, H Kretzchmar, A Raeber, U Braun, F Ehrensperger, S Hornemann, R Glockshuber, R Riek, M Billeter, K Wuthrich,
B Oesch. 1997. Prion (Prpsc)-specific epitope defined by a monoclonalantibody. Nature 390, 74-77.

Li A, HM Christensen, LR Stewart, KA Roth, R Chiesa, DA Harris. 2007. Neonatal lethality in transgenic mice expressing prion protein with a deletion of residues 105-125. EMBO J 26, 548-558.

Lopes MH, GN Hajj, AG Muras, GL Mancini, RM Castro, KC Ribeiro, RR Brentain, R Linden, VR Martins. 2005. Interaction of cellular prion and stress-inducible protein 1 promotes neuritogenesis and neuroprotection by distinct signaling pathways. J Neurosci 25, 11330-11339.

Mabbott NA, GG MacPherson. 2006. Prions and their lethal journey to the brain. Nat Rev Microbiol 4, 201-211.

Maignien T, M Shackweh, P Calvo, D Marce, N Sales, E Fattal, JP Deslys, P Couvreur, CI Lasmezas. 2005. Role of gut macrophages in mice orally contaminated with scrapie or BSE. Int J Pharm 298, 293-304.

Mallucci GR, S Ratte, EA Asante, J Linehan, I Gowland, JG Jefferys, J Collinge. 2002. Post-natal knockout of prion protein alters hippocampal CA1 properties, but does not result in neurodegeneration. EMBO J 21, 202-210

Mallucci GR, A Dickinson, J Linehan, PC Klohn, S Brandner, J Collinge. 2003. Depleting neuronal PrP in prion infection prevent disease and reverses spongiosis. Science 302, 871-874.

Martins V, A Mercadante, A Cabral, A Freitas, R Castro. 2001. Insights into the physiological function of cellular prion protein. Braz J Med Biol Res 34, 585-595.

Martins VR, R Linden, M Prado, R Walz, AC Sakamoto, I Izquierdo, RR Brentani. 2002. Cellular prion protein: on the road for functions. FEBS Letters 512, 25-28.

McDonald ST, K Sutherland, JW Ironside. 1996. Prion protein genotype and pathological phenotype studies in sporadic Creutzfeldt-Jakob disease. Neuropathol Appl Neurobiol 22, 285-292.

Mishra RS, S Basu, Y Gu, X Luo, WQ Zou, R Mishra, R Li, SG Chen, P Gambetti, H Fujioka, N Singh. 2004. Protease-resistant human prion protein and ferritin are cotransported across Caco-2 epithelial cells: Implications for species barrier in prion uptake from the intestine. J Neurosci 24, 11280-11290.

Moore RA, C Herzog, J Errett, DA Kocisko, KM Arnold, SF Hayes, SA Priola. 2006. Octapeptide repeat insertions increase the rate of protease-resistant prion protein formation. Protein Science 15, 609-619.

Neutra MR, A Frey, JP Kraehenbuhl. 1996. Epithelial M cells: gateways for mucosal infection and immunization. Cell 86, 345-348.

Oesch B, D Westaway, M Walchili, MP Mckinley, SB Kent, R Aebersol, RA Barry, P Tempst, DB Teplow, LE Hood, SS Prusiner, C Weissman. 1985. A cellular gene encodes scrapie PrP 27-30 protein. Cell 40, 735-746.

OIE, Office International des Epizooties. 2004. Bovine spongiform encephalopathy. In: Manual of diagnostic tests and vaccines for terrestrial animals (mammals, birds and bees). Vol I. $5^{\text {th }}$ ed. Paris, France,

OIE, Office International des Epizooties. 2009. Number of reported cases of bovine spongiform encephalopathy (BSE) in farmed cattle worldwide. http://www.oie.int/eng/info/en_esbmonde.htm

Pan KM, M Baldwin, J Nguyen, M Gasset, A Serban, D Groth, I Mehlhorn, Z Huang, RJ Fletterick, FE Cohen, SB Prusiner. 1993 Conversion of alpha-helices into $\beta$-sheets features in the formation of scrapie prion proteins. Proc Natl Acad Sci USA 90, 10962-10966.

Parchi P, P Gambetti. 1995. Human prion disease. Curr Opin Neurol 8, 286-293.

Peralta OA, WH Eyestone. 2009. Quantitative and qualitative analysis of cellular prion protein $(\operatorname{PrP}(\mathrm{C}))$ expression in bovine somatic tissues. Prion 3, 161-170.

Peralta OA, WR Huckle, WH Eyestone. 2011. Expression and knockdown of cellular prion protein $\left(\mathrm{PrP}^{\mathrm{C}}\right)$ in differentiating mouse embryonic stem cells. Differentiation 81, 68-77.

Premzl M, V Gamulin. 2007. Comparative analysis of prion genes. BMC Genomics 8, 1 . 
Prusiner SB. 1982. Novel proteinaceous infectious particles cause scrapie. Science 216, 136-144.

Prusiner SB. 1990. Novel structure and genetics of prions causing neurodegeneration in humans and animals. Biologicals 18, 247-262.

Prussiner SB, MR Scott. 1997. Genetics of prions. Annu Rev Genet $31,139-175$.

Prusiner SB. 1998. Prions. Proc Natl Acad Sci USA 95, 13363-13383.

Roucou X, PN Giannopoulos, Y Zhang, J Jodoin, CG Goodyer, A LeBlanc. 2005. Cellular prion protein inhibits proapoptotic Bax conformational change in human neurons and in breast carcinoma MCF-7 cells. Cell Death Differ 12, 783-795.

Russelakis-Carneiro M, GP Saborio, L Anderes, C Soto. 2002. Changes in the glycosylation pattern of prion protein in murine scrapie. Implications for the mechanism of neurodegeneration in prion diseases. J Biol Chem 277, 36872-36877.

Ryan AM, JE Womack. 1993. Somatic cell mapping of the bovine prion protein gene and restriction fragment length polymorphism studies in cattle and sheep. Anim Genet 24, 23-26.

Santuccione A, V Sytnyk, I Leshchyns'ka, M Schachner. 2005. Prion protein recruits its neuronal receptor NCAM to lipid rafts to activate p59fyn and to enhance neurite outgrowth. J Cell Biol 169, 341-354.

Schaller O, R Fatzer, M Stack, J Clark, W Cooley, K Biffiger K, S Egli, M Doherr, M Vandevelde, D Heim, B Oesch, M Moser. 1999. Validation of a Western immunoblotting procedure for bovine PrPSc detection and its use as a rapid surveillance method for the diagnosis of bovine spongiform encephalopathy (BSE). Acta Neuropathol (Berl) 98, 437-443.

Schmerr MJ, A Jenny. 1998. A diagnostic test for scrapie-infected sheep using a capillary electrophoresis immunoassay with fluorescentlabeled peptides. Electrophoresis 19, 409-414.

Schwartz M. 2003. Bovine Spongiform Encephalopathy (BSE) In: Schneider E (ed). How the cows turned mad. $1^{\text {st }}$ ed. University of California Press, Berkeley, California, USA, Pp 25-34.

Shortman K, YJ Liu. 2002. Mouse and human dendritic cell subtypes. Nature Rev Immunol 2, 151-161.

Siso S, L Gonzalez, M Jeffrey. 2010. Neuroinvasion in prion diseases: the roles of ascending neural infection and blood dissemination. Interdiscip Perspect Infect Dis 747892.

Solforosi L, JR Criado, DB McGavern, S Wirz, M Sanchez-Alavez, S Sugama, LA DeGiorgio, BT Volpe, E Wiseman, G Abalos, E Masliah, D Gilden, MB Oldstone, B Conti, RA Williamson. 2004. Cross-linking cellular prion protein triggers neuronal apoptosis in vivo. Science 303, 1514-1516.

Soto C. 2006. Prions. Prions: The new biology of proteins. $1^{\text {st }}$ ed. CRC Press, Boca Raton, FL, USA.

Sparkes RS, M Simon, VH Cohn, RE Fournier, J Lem, I Klisak, C Heinzmann, C Blatt, M Lucero, T Mohandas, SJ DeArmond, D Westaway, SB Prusiner, LP Weiner. 1986. Assignment of the human and mouse prion protein genes to homologous chromosomes. Proc Natl Acad Sci USA 83, 7358-7362.

Steele AD, JG Emsley, PH Ozdinler, S Lindquist, J Macklis. 2006. Prion protein $(\mathrm{PrPC})$ positively regulates neural precursor proliferation during developmental and adult mammalian neurogenesis. PNAS 103, 3416-3421.
Stewart RS, DA Harris. 2001. Most pathogenic mutations do not alter the membrane topology of the prion protein. J Biol Chem 276, 2212-2220.

Taylor DM. 2000. Inactivation of transmissible degenerative encephalopathy agents: a review Vet $J 159,10-17$.

Telling GC, M Scott, J Mastrianni, R Gabizon, M Torchia, FE Cohen, SJ DeArmond, SB Prusiner. 1995. Prion propagation in mice expressing human and chimeric PrP transgenes implicates the interaction of cellular PrP with another protein. Cell 83, 79-90.

Terry LA, S Marsh, SJ Ryder, SA Hawkins, GA Wells, YI Spenser. 2003. Detection of disease-specific PrP in the distal ileum of cattle exposed orally to the agent of bovine spongiform encephalopathy. Vet Rec 152, 387-392.

Thorne L, LA Terry. 2008. In vitro amplification of PrPSc derived from the brain and blood of sheep infected with scrapie. J Gen Virol 89, 3177-3184.

Tremblay P, E Bauzamondo-Bernstein, C Heinrich, SB Prusiner, SJ DeArmond. 2007. Developmental expression of PrP in the postimplantation embryo. Brain Res 30, 60-67.

USDA, United States Department of Agriculture. 2005. Animal and Plant Health Inspection Service. Factsheet, BSE Confirmatory Tests, USA.

Van Keulen LJ, A Bossers, F van Zijderveld. 2008. TSE pathogenesis in cattle and sheep. Vet Res 39, 24.

Vassallo N, J Herms. 2003. Cellular prion protein function in copper homeostasis and redox signaling at the synapse. J Neurochem 86, 538-544.

Wechselberger C, S Wurm, W Pfarr, O Hoglinger. 2002. The physiological functions of prion protein. Exp Cell Res 281, 1-8.

Wells GA, AC Scott, CT Johnson, RF Gunning, M Hancock, M Jeffrey, M Dawson, R Bradley. 1987. A novel progressive spongiform encephalopathy in cattle. Vet Rec 121, 419-420.

Wells GA, RD Hancock, WA Cooley, MS Richards. 1989. Bovine spongiform encephalopathy: diagnostic significance of vacuolar changes in selected nuclei of the medulla oblongata. Vet Rec 125, 521-524.

Wells GA, JW Wilesmith. 1995. The neuropathology and epidemiology of bovine spongiform encephalopathy. Brain Pathol 5, 91-103.

Westergard L, HM Christensen, DA Harris. 2007. The cellular prion protein (PrPC): Its physiological function and role in disease. Biochim Biophys Acta 1772, 629-644.

Wong BS, T Liu, R Li, T Pan, RB Petersen, MA Smith, P Gambetti, G Perry, JC Manson, DR Brown, MS Sy. 2001. Increased levels of oxidative stress markers detected in the brains of mice devoid of prion protein. J Neurochem 76, 565-572.

Zanata SM, MH Lopes, AF Mercadante, GN Hajj, LB Chiarini, R Nomizo, AR Freitas, AL Cabral, KS Lee, MA Juliano, E de Oliveira, SG Jachieri, A Burlingame, L Huang, R Linden, RR Brentani, VR Martins. 2002. Stress-inducible protein 1 is a cell surface ligand for cellular prion that triggers neuroprotection. EMBO J 21, 3307-3316.

Zhang CC, AD Steele, S Lindquist, HF Lodish. 2006. Prion protein is expressed on long-term repopulating hematopoietic stem cells and is important for their self-renewal. Proc Natl Acad Sci USA 103, 3416-3421. 